\title{
Discussion on Practice Innovation Reform of Sports Anatomy
}

\section{Chang Zimin and Jiang Yu}

(NanChang Institute of Science and Technology, Nanchang, 330108)

\author{
Keywords: Sports Anatomy; Practice; Reform; Innovation
}

\begin{abstract}
With the reform of college education system and the propose of science and technology, innovative personnel training mode, sports anatomy experimental curriculum reform is imperative. Sports anatomy experiment is a course which takes anatomical knowledge as the basis, sports practice as the basis and solving practical problems in physical education as the goal. The current experimental class hours are too few, experimental content and method of professionalism is not strong, and the experimental assessment method is not reasonable. This paper presents the reform of experimental class, which is to reform the class time, the experiment project and examination system, in order to drive the experimental curriculum reform the sports anatomy. This paper starts from the characteristic construction of sports training in institutions of higher learning and focuses on the training objectives of sports training. It systematically and comprehensively studies the construction of sports anatomy curriculum and teaching contents so as to excavate and innovate new professional features and highlights of sports anatomy, and thus enrich the content and innovative value of sports anatomy curriculum.
\end{abstract}

\section{Introduction}

Sports anatomy is a professional basic course for physical education. As a leading course for follow-up courses, such as sports physiology, sports biomechanics and sports health science, sports anatomy will lay a solid theoretical foundation for students to successfully follow the courses. In the current compression of colleges and universities, in the context of giving the choice to students, as well as the current situation that the class time is less, the teaching tasks are heavy, the knowledge of teaching is more, students foundation is weak, the employment pressure of sports education is large, how to improve the effect of students' class and to enhance students' professional identity is very important. This paper starts from the characteristic construction of sports training in institutions of higher learning and focuses on the training objective of sports training and makes a systematic and comprehensive research on the curriculum construction and teaching contents of sports anatomy.

\section{Sports Anatomy}

Sports anatomy is an integral part of sports morphology. It is a new discipline that studies the influence and regularity of sports on human body structure based on normal human anatomy. It focuses on the movement of organs and its closely related cardiovascular system and nervous system, its specific research topics are: the range of joint motion and muscle force, the impact of mechanical force on bone tissue, muscle training during exercise vascular morphology Changes in the shape and structure of the muscle fibers, changes in the ultimate shape of the movement and rotation and linear acceleration of the balance of the impact of organ movement. The characteristics of the exercise anatomy experiment are as follows:

(1) Based on anatomical knowledge

By definition, sports anatomy is based on the anatomy of the human body to study the impact of sports on the structure of the human body. The content covers the basic anatomy and sports science theory. The basis of anatomy includes the morphological characteristics of various parts of the human body, including the basic knowledge of cells, tissues, motor system, internal organs, vasculature, nervous system, sensory organs, endocrine and so on. 
(2) Rely on exercise practice

Sports anatomy is not simply a basic theory courses, but an applied course. Its teaching purpose is to enable students to acquire sufficient knowledge of anatomy, which will be useful for sports practice. Through the course, physical education students should deepen the understanding of sports techniques and physical exercises.

\section{Current Problems in Experimental Teaching of Sports Anatomy}

(1) Experimental class attached to the theory class

Less emphasis is placed on experimental teaching in our country's education mode. The basic course teaching in physical education department regards experimental class as an adjunct to theoretical class, which is mainly arranged in the experimental class with less time, generally about $1 / 6$ of the theoretical class. Some teachers of some sports education departments even take up experimental classes, making the originally few experimental classes became ever few. Therefore, students always feel that there are to many experimental contents, and it is difficult to complete the experiment contents within the stipulated time or to achieve the purpose of the experiment. On the other hand, there are too few experimental projects are set up.

(2) Little professional

At present, the sports anatomy experiments of many sports colleges in our country fully apply medical model. The experimental class focuses on the structure of the human body to make a point of introduction, and just pays little attention to the combination of theory and the practice. Also, many of the teachers in the class graduated from medical colleges and universities, lacking in sports experience and sports related knowledge. Sports anatomy experiment project is basically to observe the cell morphology, bone, joint, muscle, viscera and so on. Although there are some exercises that sometimes occur during anatomy experiments, they are low in weight. And the focus of sports anatomy should be combined with the practice of sports, sports should be better combined with the professional, in order to better serve the practice of sports.

(3) Less design and comprehensive experiments

The traditional experimental project and content is to observe the structural features of tissue cells, bone, joints, skeletal muscle, internal organs and nerves. Demonstrative, confirmatory experiments are more, while design and comprehensive experiments are less. Many students think that sports anatomy is rote memorization, sports anatomy experiments are mostly observed specimens, models, pictures and so on. This imprisons the student's creativity and design. It is not conducive to the mastery of anatomical knowledge and it is not conducive to students' independent innovation ability and learning initiative.

\section{Practice Innovation and Reform}

(1) Teaching content system reform

Combined with the actual characteristics of sports education, the teaching content of Sports Anatomy is detailed planned and arranged, which pays more attention to the expansion of students' knowledge and ability of theoretical analysis. First of all, pay attention to make the combination between the theory and the practice in sports anatomy and physical education to improve students' ability to analyze problems and to solve problems. For example, when talking about the muscle's fixed point and moving point, the lecturer uses the lectern to do the push-ups and let the students know the position of the moving point and the fixed point in the biceps and brachial muscles. When talking about ways to develop muscle strength, students are asked to consider that which muscle strength is developed in the pull-ups, overhanging legs, sit-ups and other student-familiar sports actions in order to analyze and solve problems. 


\section{(2) Teaching method reform}

PBL teaching method is implemented in the experimental class. The main characteristics of PBL teaching method is student-centered teaching method under the guidance of the instructor. The method emphasizes learning should be set in a complex and meaningful problem situation, and the scientific knowledge hiding in the problem should be learned by cooperation. Skills to solve problems should be formed and students' ability to learn independently and innovative spirit should be developed.In order to improve the enthusiasm and initiative of the students in the experimental class, PBL teaching method is greatly promoted in the experimental teaching of sports anatomy. The implementation of student-centered PBL teaching method in experiment class makes students' ability to learn independently in class be further enhanced. The class atmosphere during the class is activity and the discussion is heated. Students have high enthusiasm for class. The studying results and test results are more excellent than other classes.

(3) Anatomy experiments are closely integrated with the subject curriculum

Teaching should focus on exercise practice, at the appropriate time, bring students out of the classroom for experiment. Carry out operation analysis experiments in track and field, volleyball room, gymnastics room, martial arts museum, so that students can see the contracted muscles and experience muscle contraction when learning anatomy knowledge on familiar sports arenas. In the process, students can get a deeper understanding of the knowledge in class. Of course, in this process, teachers should prepare for the corresponding actions, such as explaining the movement of lower extremity muscles, pointing the toes and clenching the buttocks, cross-basket running and other activities can be used. When explaining the upper limb muscles, throwing the shot or volleyball and jumping and spiking can be used.

\section{Conclusion}

The teaching reform of sports anatomy is a long-term process. The learning conditions of students, the development and changes of society, and the direction of the development of disciplines will place new demands on teaching. However, reforms are inseparable from the scientific, inspiring, interactive, contemporary and applicability. The overall goal of personnel training in higher education is to foster innovative spirit and practical ability and to cultivate comprehensive qualities and abilities. Sports anatomy experimentmust be close to the goal of personnel training both on experimental content, experimental projects and assessment methods. However, the reform of sports anatomy experimental course can not be completed overnight, it needs constant developing and improving.

\section{References}

[1] Finberg M, Braham R, Goodman C, et al. Effects of electrostimulation therapy on recovery from acute team-sport activity[J]. International Journal of Sports Physiology \& Performance, 2013, 8(3):293-299.

[2] Sperlich B, Achtzehn S, Buhr M, et al. Salivary cortisol, heart rate, and blood lactate responses during elite downhill mountain bike racing[J]. International Journal of Sports Physiology \& Performance, 2012, 7(1):47.

[3] Svensson D. How Much Sport is there in Sport Physiology? Practice and Ideas in the Stockholm School of Physiology at GCI, 1941-1969[J]. International Journal of the History of Sport, 2013, 30(8):892-913.

[4] Håkan Larsson. Sport physiology research and governing gender in sport — a power-knowledge relation?[J]. Sport Education \& Society, 2013, 18(3):334-348.

[5] Pérez Córdoba E. Physiology and sport psychology: conceptual and methodological aspects[J]. Cuadernos De Psicología Del Deporte, 2011.

[6] Gleason P T, Kim J H. Exercise and Competitive Sport: Physiology, Adaptations, and Uncertain Long-Term Risks[J]. Current Treatment Options in Cardiovascular Medicine, 2017, 19(10):79. 
[7] Losnegard T, Hallén J. Physiological differences between sprint- and distance-specialized cross-country skiers[J]. International Journal of Sports Physiology \& Performance, 2014, $9(1): 25$.

[8] Burke L M, Pyne D B. Bicarbonate loading to enhance training and competitive performance[J]. International Journal of Sports Physiology \& Performance, 2007, 2(1):93.

[9] Brearley M B, Finn J P. Responses of motor-sport athletes to v8 supercar racing in hot conditions[J]. International Journal of Sports Physiology \& Performance, 2007, 2(2):182.

[10] Massidda M, Scorcu M, Calò C M. New genetic model for predicting phenotype traits in sports[J]. International Journal of Sports Physiology \& Performance, 2013, 9(3):554-560.

[11] de Freitas V H, Pereira L A, de Souza E A, et al. Sensitivity of Yo-Yo IR and Cardiac Autonomic Responses to Training in Futsal Players[J]. International Journal of Sports Physiology \& Performance, 2014, 10(5):553.

[12] Barrett S, Midgley A, Lovell R. PlayerLoad 鈩 reliability, convergent validity, and influence of unit position during treadmill running[J]. International Journal of Sports Physiology \& Performance, 2014, 9:945-952. 